\title{
SUSTAINABILITY AND RESILIENCE IN THE OLD TOWN OF NORCIA, ITALY
}

\author{
STEFANIA TRIFAN, CRISTINA OLGA GOCIMAN \& CRISTINA VICTORIA OCHINCIUC \\ Ion Mincu University of Architecture and Urbanism, Bucharest, Romania
}

\begin{abstract}
The ancient towns have some characteristics of the sustainable city. The buildings are preserved, improved and adapted. The Sustainable Development Goals are fulfilled, and Norcia in Italy was a good example of how to live in a town with wonderful history and important economic achievements using local food technology. After the 2016 earthquakes, Norcia had to respond to a new challenge: to be functional and restore the affected parameters. The study for presentation includes the restructuring of the vital functions of the town while keeping the local community. The compact old town being damaged required the relocation of part of the population near the existing industrial zone located outside the defence walls (which, up to the earthquake, kept almost all of the residential area within the ancient area). The methods for investigation involve diagrams and conclusion after direct observation. Sustainable development also involves resolving living in safe spaces, and local community continues to grow by balancing the preservation of old damaged buildings, but with major implications for their repair, with the optimal operation in separate areas up to the rehabilitation of damaged buildings. According to the 2015 Paris Agreement on Climate Change and the Sustainable Development Goals, the food sector, tourism and construction can offer good support for development, and Norcia has all the premises for the rebuilding and reconstruction of damaged areas, so that it reaches a sustainable way of appropriate habitation again.

Keywords: old town, ancient area, earthquake, damage, defence walls, church, buildings, preservation.
\end{abstract}

\section{INTRODUCTION}

This paper presents the sustainable characteristics of the old towns, values that are also found in Norcia, Italy, and after this analysis there are presented elements regarding the reconstruction and adaptation to the new conditions after the seismic events (see Fig. 1).

In 2016, in the center of Italy, especially in the area of localities Norcia, Amatrice, Cascia from Umbria region, there were a succession of earthquakes that had great economic, social and cultural impact. The earthquakes recorded on August 24th 2016 and October 30th 2016 had a different impact for the neighboring localities regarding losses. In Norcia (see Fig. 2), no deaths have been integrated as a result of these earthquakes, but there were material losses, for in a part of the old town access was restricted, and several churches were affected, among which was the church of St. Benedict, built in memory of the saint born in Norcia.

The study carries out a socio-economic, cultural, heritage and constructive background analysis. Recovery of resources is a priority for the old town, and the study aims to identify them, to show how these values are preserved and to keep the spirit of the place.

\section{SUSTAINABLE CHARACTERISTICS OF NORCIA OLD TOWN}

The old town Norcia that was founded in antiquity has the characteristics specific to the old cities: enclosure enclosed with defense walls, sometimes this wall being incorporated in constructions at the exterior limits of the fortress, and the street plot inscribed in this perimeter [2]. Sustainable Development Goals Study for Norcia was prepared, but all the information's has a general character [3]. 


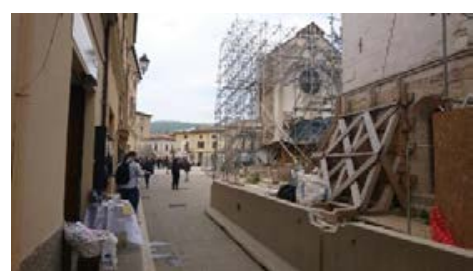

(a)

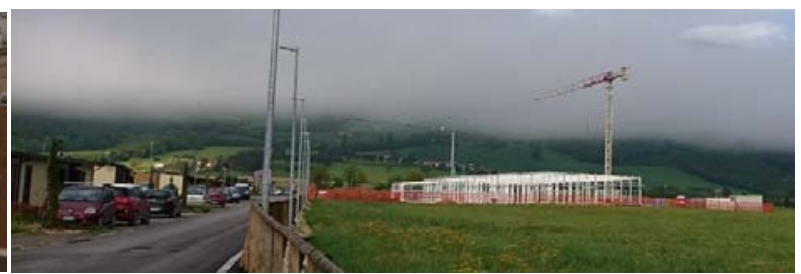

(b)

Figure 1: (a) Ancient town affected by the earthquake; (b) New industrial development and new camp for the earthquake victims, (C) Stefania Trifan, 2018.

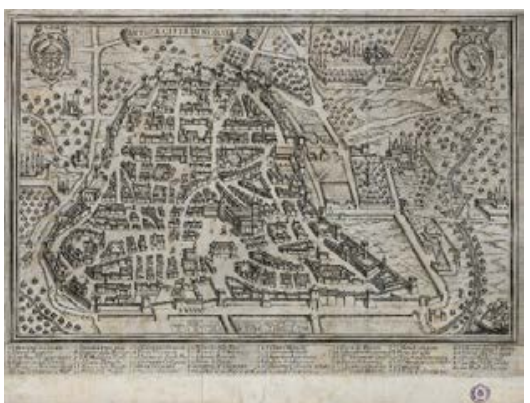

(a)

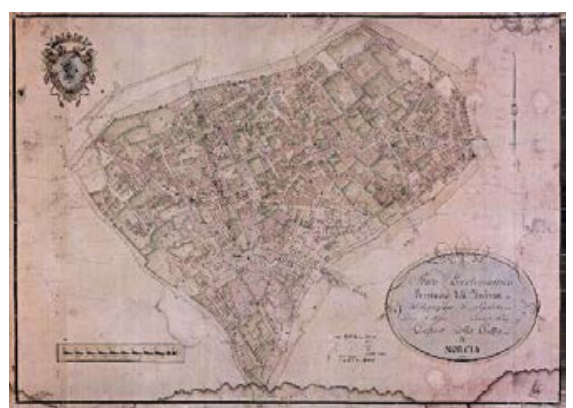

(b)

Figure 2: (a) Map with stamp from the Roma State Archive; (b) Norcia map from 1820 Source: Workshop documents "Earthquake and historical centers. The urban walls of Norcia". (Source: Data bank: Biblioteca Riccardiana - Firenze [1].)

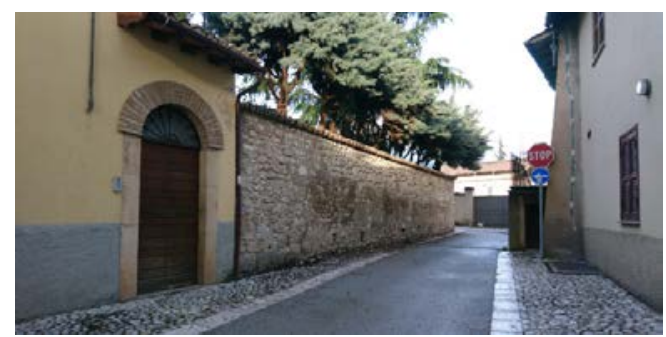

(a)

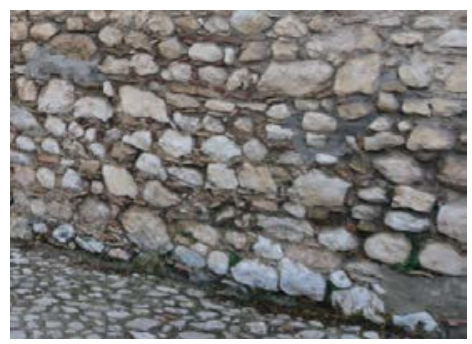

(b)

Figure 3: (a) Local materials: stone, brick, tiling, paving stone; (b) Masonry detail made of the reused materials, C Stefania Trifan, 2018.

\subsection{Constructive features}

Localities of this type represent several characteristics of sustainable cities, and some of these aspects are presented below. The stone, the local material for the construction (see Fig. 3), is used for strength and durability and it can be reused. The use of the stone for the buildings also gives a good resistance in case of fire. 
The buildings are kept for several generations, therefore improvements are made that do not generate so much waste that would result from the demolition of the old constructions and the construction of new ones.

Larger walls of older buildings are appreciated due to the lower heat transfer, thus consuming less energy.

\subsection{Transport versus pedestrian path}

The perimeter walls of the old town Norcia, as well as the street layout, encourage pedestrian access, with bicycles or smaller cars that have a lower fuel consumption. In the town, there are cross sports competitions, which means that the population has a healthy lifestyle.

\subsection{Cultural identity}

Norcia has a strong identity, of Etruscan and Romanian origins; it is the town where Saint Benedict from Norcia was born in 480 . Norcia was affected several times by earthquakes (especially in 1763, 1859, 1979 and 2016), but with all the losses, Norcia remained functional in the same perimeter.

Several churches and monasteries were strongly affected by the earthquakes in 2016: St Benedict basilica, built in the 13th century, on the site of an older church building where St. Benedict was born, the church of Sant'Agostino, the church of Santa Maria Argentea, San Lorenzo Basilica the oldest church from Norcia, Museum in the papal fortress, the Castellina. Cultural identity encouraged continuity in the same location, with the use of the same specific materials, especially stone.

\subsection{Life on land}

The old age of the local community and of the ancient personalities that came from these places, such as the mother of Emperor Vespasian, of Saint Benedict and of the twin sister Scholastica, encouraged the preservation of identity and continuity in these places. "Dialetto Norcino" is a peculiarity language of the area and it is part of the local specificity. Through the data listed, it can be said that the old town Norcia has a homogeneous image that represents an asset for the further preservation of its own characteristics. Some of the residents outside Norcia preferred to live in containers located on the property near the house after the earthquake in 2016.

The identity is also correlated with perception, so visually the inhabitants of Norcia request the restoration of the fortress as it was before the earthquake.

\subsection{Local products}

In addition to the local construction products listed above, Norcia is known mainly because of food products: specific sausages, black truffles and less for cheese and chocolate production. The "Norcineria", the butcher's shop, has entered in the Italian language especially through the local quality products that use products made from wild boar.

\subsection{Responsible consumption and production}

The use of local products, through commercialization (see Fig. 4), encourages the development of the area, and on the local level, it reduces the consumption of other imported products that would require transport, deposits, etc., transposed later in pollution. 


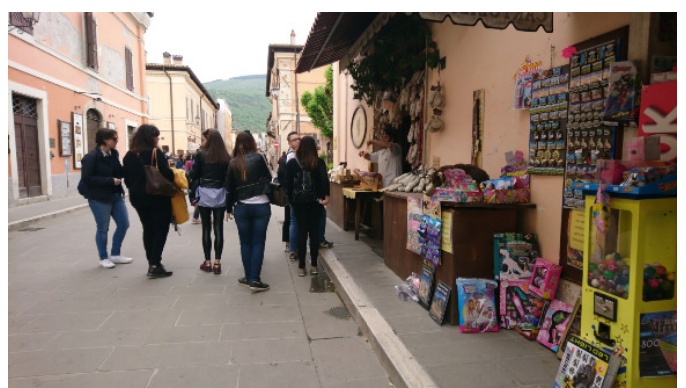

(a)

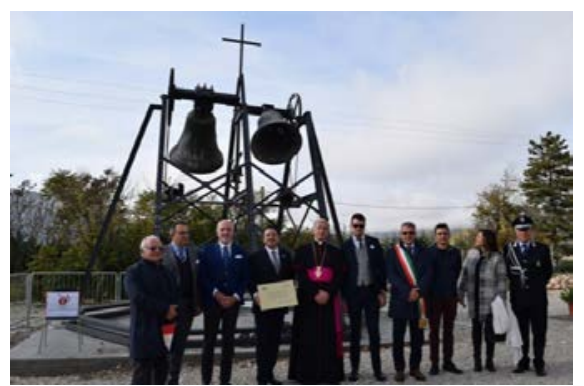

(b)

Figure 4: (a) Street trade for the promotion of local products and point of sale with souvenirs, (C) Stefania Trifan, 2018; (b) Recovered bells to remember. (Source: TuttOggi [4].)

\subsection{Agro-tourism}

Monti Sibillini National Park is near the town, with the uncontaminated nature in which forests are found. These areas are highly appreciated for products that are found in nature such as: mushrooms, blueberries, blackberries and raspberries. Outdoor activities are encouraged and there are facilities available for riding, cycling, fishing, rafting, and climbing. These activities encourage a healthy lifestyle, and agro-tourism uses the specificity of the region and maintains a sustainable development. Nearby Norcia is Castelluccio, which offers a very beautiful panorama that attracts many tourists, especially when fields are full of blooming wild flowers.

According to the situation described, several UN Sustainable Development Goals requirements are met. The characteristics, apart from sustainable features, can conclude that Norcia has owns "genius loci" [5] that reflects a unique character that must be preserved.

\section{DAMAGE AFTER THE 2016 EARTHQUAKES}

The earthquakes that have affected the locality the most in the last period were on 24th August 2016 and 30th October 2016 (see Fig. 5 and Table 1).

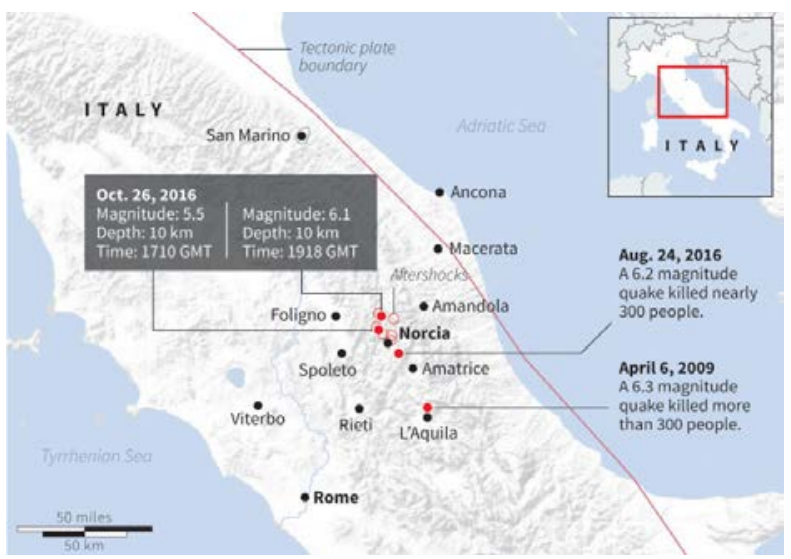

Figure 5: Earthquakes in Italy. (Source: U.S. Geological Survey [6].) 
Table 1: 2016 Norcia earthquakes data with a Richter magnitude scale of more than 5.5.

\begin{tabular}{|c|c|c|c|c|c|c|}
\hline \multirow{3}{*}{$\begin{array}{l}2016 \text { Norcia } \\
\text { earthquakes }\end{array}$} & \multicolumn{6}{|c|}{ Earthquakes data } \\
\hline & \multirow{2}{*}{$\begin{array}{l}\text { Richter } \\
\text { scale }\end{array}$} & \multirow{2}{*}{$\begin{array}{l}\text { GMT } \\
\text { hour }\end{array}$} & \multirow{2}{*}{$\begin{array}{l}\text { Hypocenter } \\
\text { depth }\end{array}$} & \multicolumn{3}{|c|}{ Epicenter } \\
\hline & & & & Location & Latitude & Longitude \\
\hline 24 August & 6.2 & $04: 36: 32$ & $\begin{array}{c}10 \mathrm{~km} \\
(6.2 \mathrm{miles})\end{array}$ & Norcia & 42.71 & 13.17 \\
\hline 24 August & 5.5 & $05: 33: 29$ & $\begin{array}{c}10 \mathrm{~km} \\
(6.2 \mathrm{miles}) \\
\end{array}$ & Norcia & 42.79 & 13.15 \\
\hline 26 October & 5.5 & $17: 10: 36$ & $\begin{array}{c}8.7 \mathrm{~km} \\
\text { (5.7 miles) }\end{array}$ & Macerata & 42.88 & 13.12 \\
\hline 26 October & 6.1 & $19: 18: 05$ & $\begin{array}{c}10 \mathrm{~km} \\
(6.2 \mathrm{miles}) \\
\end{array}$ & Macerata & 42.90 & 13.12 \\
\hline 30 October & 6.6 & $06: 40: 17$ & $\begin{array}{c}9.4 \mathrm{~km} \\
\text { (5.4 miles) }\end{array}$ & Perugia & 42.84 & 13.11 \\
\hline
\end{tabular}

The earthquake of 24th August damaged several buildings in Norcia and caused the death of 297 people: 234 in Amatrice, 11 in Accumoli and 49 in Arquata del Tronto [7].

\subsection{Measures prior to the 2016 earthquakes}

On 1859, after a strong earthquake in Norcia, the Papal State imposed that buildings should not be higher than 3 floors. Recently, after the earthquake in 1979, consolidation measures were taken, and in 2005 [8] due to land displacements in the area, studies were conducted on the nature of the lands, highlighting the fact that Norcia is located in a continue area with seismic risk.

\subsection{Consequences after the earthquakes in 2016}

Immediately after the 24th August 2016 earthquake, the population sheltered in the free spaces in the center of Norcia, and after the 30th October 2016 earthquake there were major damages to the churches, but fortunately no human lives were lost (see Figs 6 and 7).

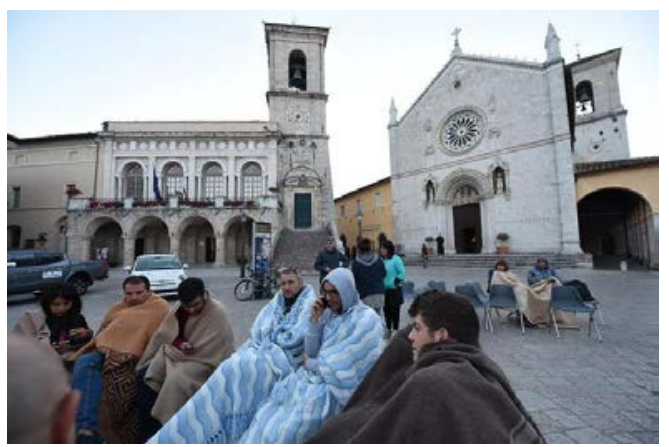

(a)

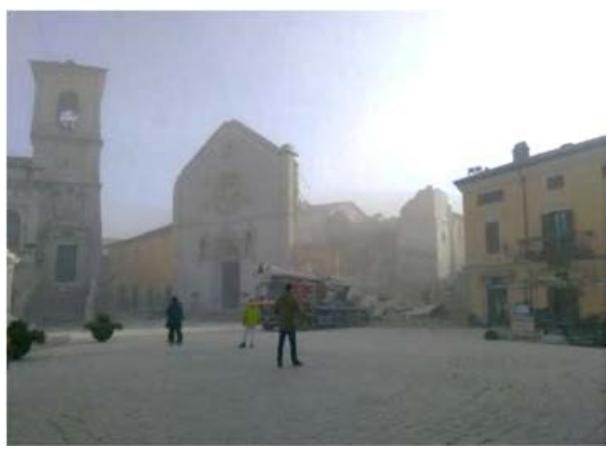

(b)

Figure 6: (a) After the 24th August 2016 earthquake, people sheltered on the Piazza San Benedetto; (b) After the 30th October 2016 earthquake, the church St Benedict collapses. (Source: Pistolesi, 2016 [8].) 
(a)

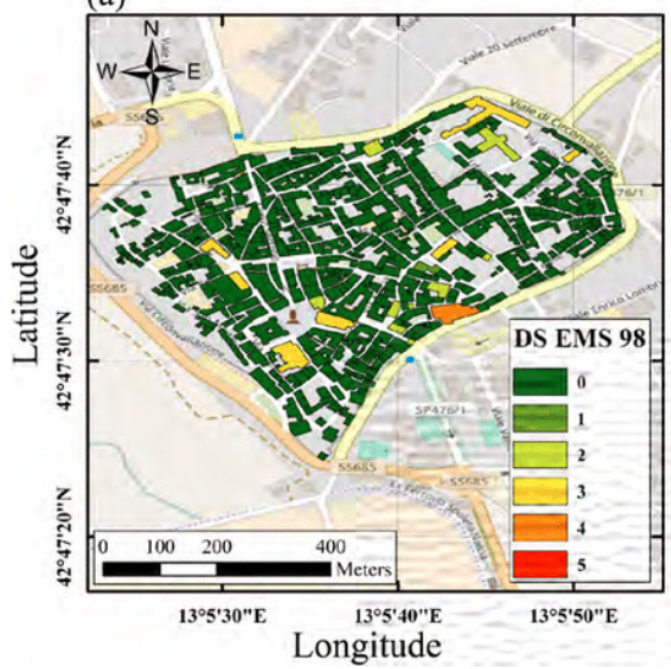

(b)

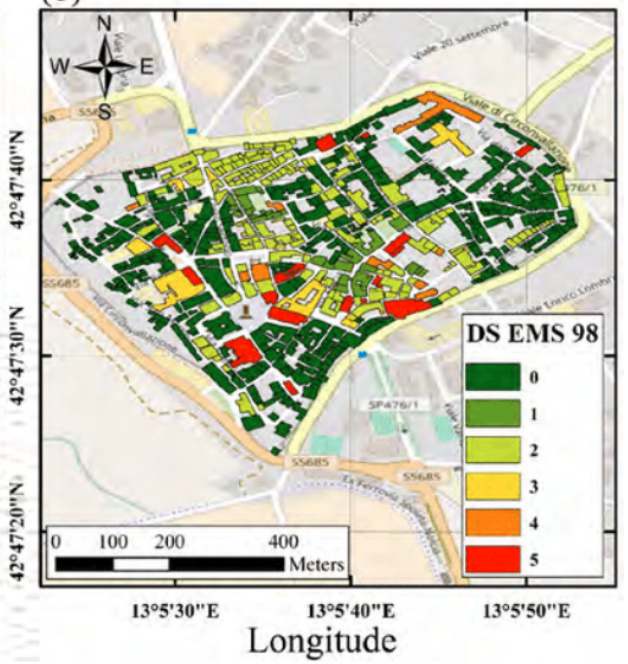

Figure 7: (a) Damage after the 24th August 2016 earthquake; (b) Damage after 30th October 2016 earthquake. (Source: Sextos, 2018 [11].)

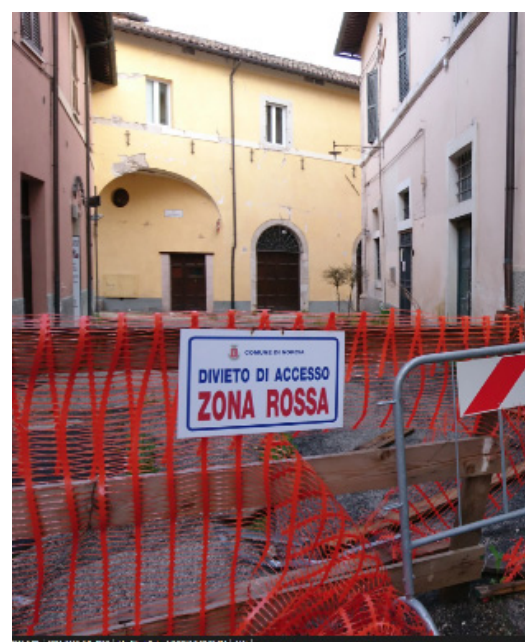

(a)

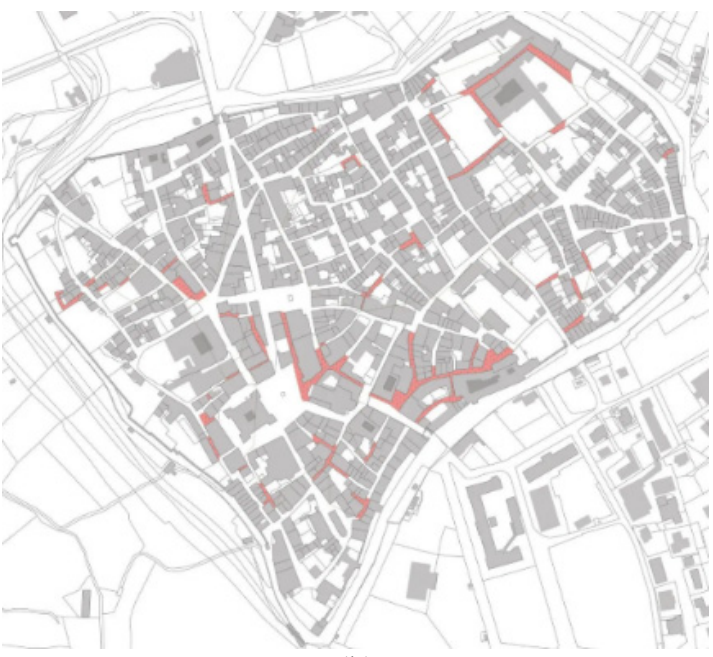

(b)

Figure 8: (a) The area with an access ban, (C) Stefania Trifan, 2018; (b) Prohibited areas map. (Source: Comune di Norcia [10].)

Due to the fact that several buildings are at risk to collapse at a possible new earthquake, areas with access restrictions have been established (see Fig. 8).

Preservation measures for current constructions are necessary, because there is a risk of further degradation if they are not used. 


\section{RESILIENCE}

The mayor and the president of the region focused on the reopening of some activities between the city walls with the hope of returning to the current activities of Norcia before the 2016 earthquakes. For the continuity of the activities there are the following typologies in Norcia: continuation on the same site by disposing of containers if this was possible (see Fig. 9), and relocation of the inhabitants by building of the SAE emergency housing solutions on the greenfield located at the limit of the locality outside the walls. For the inhabitants it was necessary to adapt to the new situations, to the new living conditions, to another route to the workplaces in the industrial area, to find other safer areas for spending leisure time. The shops, the cafes, the restaurants, the theater, the museum were closed so the inhabitants were also affected from the point of view of the recreational locations. One of the biggest losses and challenges was the loss of the churches that collapsed after the earthquake from 30th November 2016, the monasteries inside the locality were forced to relocate, and the inhabitants to adapt to the loss of churches by which they identified themselves spiritually. The citizens of Norcia organize periodically festivals, various exhibitions and competitions for the raising of funds. Unfortunately, the process of recovery and adaptation is long and arduous and requires the involvement of authorities and citizens.

\section{RECONSTRUCTION AND FURTHER DEVELOPMENTS}

After the earthquakes from 2016, the emergency construction measures were taken to avoid the collapse of damaged buildings (Fig. 10).
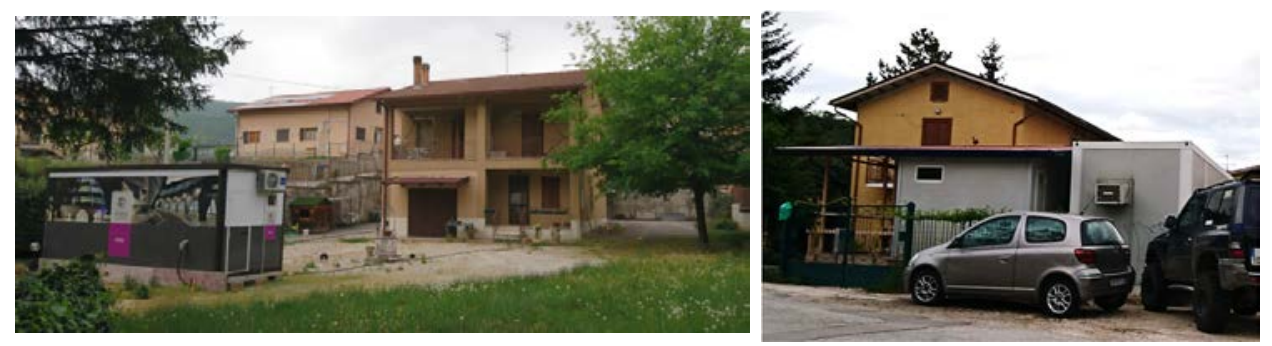

Figure 9: Properties outside the old town that have mounted containers in the courtyard, (C) Stefania Trifan, 2018.

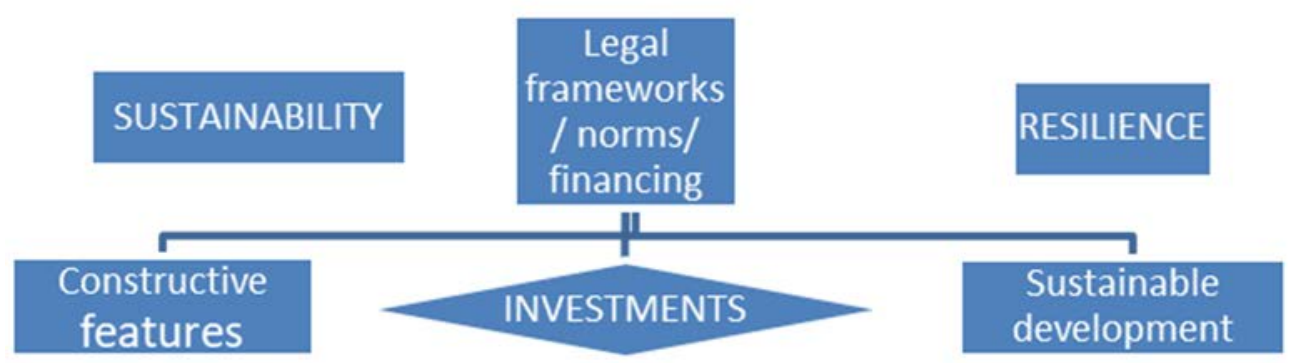

Figure 10: Sustainability/resilience diagram. 


\subsection{The emergency construction measures}

Immediately after the earthquake, measures were taken to monitor the existing constructions, in order to avoid an immediate collapse in the event of the emergence of a new earthquake [12]. Reinforcement and securing of the structures were implemented at the building with structural damages using the bracing, jacketing, the installation of metal stays, the erection of barriers [13] (see Fig. 11). These measures were taken to avoid the collapse of the buildings and for the citizens' safety.

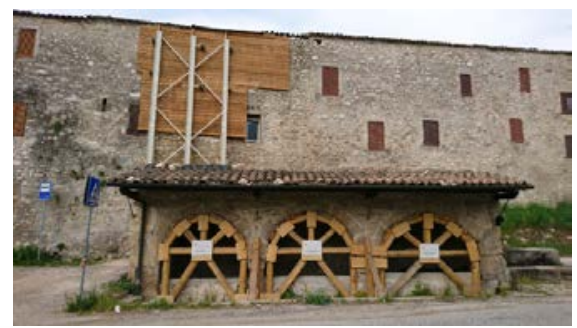

(a)

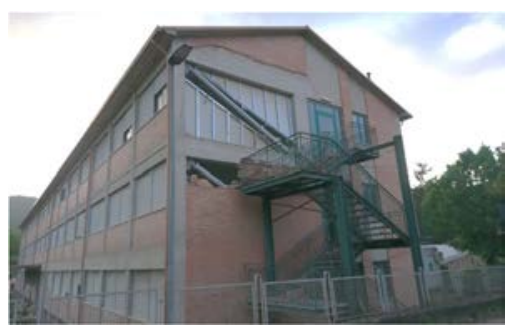

(b)

Figure 11: (a) Safe outer wall of enclosure and succession of arches; (b) Reinforcement, bracing at an existing school, (c) Stefania Trifan, 2018.

5.2 Measures regarding the affected population and the safe relocation of local administrations from damaged buildings

After the earthquakes in 2016, urgent measures were taken to secure the population and institutions, so that in 2018 when the data for this paper were collected, the school, the carabineers, the mayor's office and the fire station were relocated in containers on land located outside. The hospital kept its old location, but some departments with the construction risk from the hospital were moved in containers disposed on the ground inside of the hospital courtyard. Regarding the measures that are taken to secure certain objectives, minimum restrictive measures must be taken. There are higher risks of fires and the removal of the rubble and the dismantling of the ruins are more probable to occur (see Fig. 12). In the Norcia, 606 emergency housing solutions (SAE) fit approximately 1500 people (Fig. 13) [16].

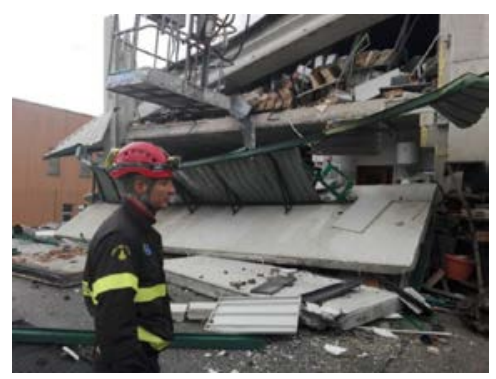

(a)

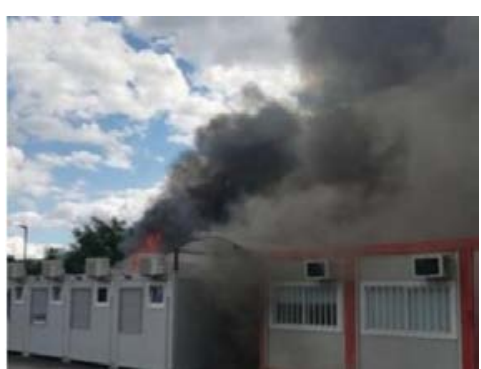

(b)

Figure 12: (a) Rescue action for Norcia archive (Source: La Voce del Territorio, 2017 [14]); (b) Municipality containers were damaged by fire (Source: QuotidianodellUmbria, 2017 [15].) (C) Stefania Trifan, 2018. 


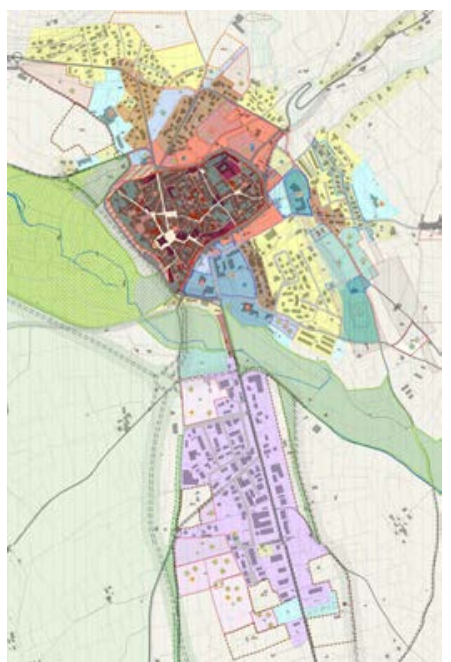

(a)

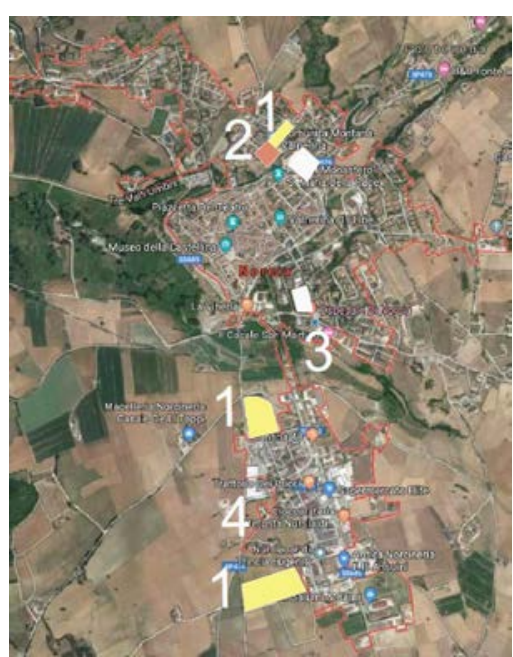

(b)

Figure 13: (a) Norcia - General Regulatory Plan (Source: Comune di Norcia, 2019 [17]); (b) Resilience plan. (1) SAE (emergency housing solutions); (2) Community Montana Valnerina; (3) Norcia Hospital; (4) Norcia firefighters detachment. (Source: Google Maps, 2019 [18].)

\subsection{Measures regarding the raising of funds for reconstruction}

An important contribution to the restoration of the areas affected by the earthquake and especially to finance the restoration of the Basilica of San Benedetto in Norcia was made by the European Commission, which allocated funds for reconstruction [19]. Therefore, the preservation and continuation of activities in the affected areas are aimed at preserving the old town Norcia. However, in 2019 the population is unhappy with the pace at which all reconstruction processes are carried out (see the camp casualties in Fig. 14).

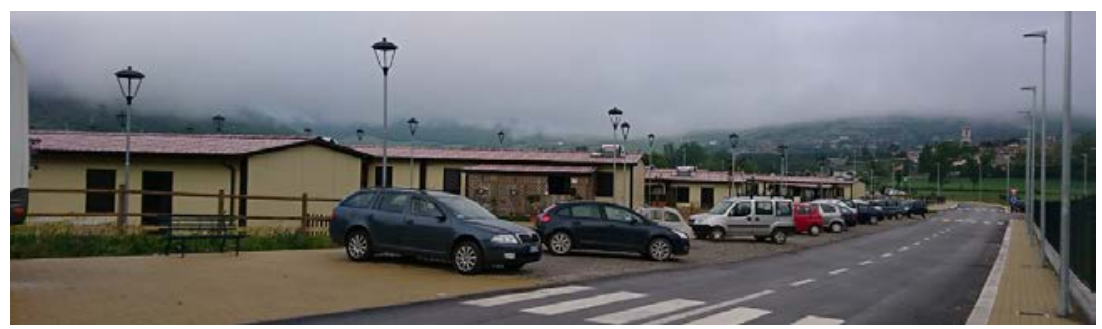

Figure 14: Camp casualties built after the earthquakes, (C) Stefania Trifan, 2018.

\section{CONCLUSIONS}

The cultural identity in the old cities is one of the relevant characteristics, so it is important to take in consideration this fact, because there is a clear determination to continue in the same area of previous activities before the 2016 earthquake from Norcia. The measures taken regarding the diminution of the energy consumption and the realization of sustainable 
investments, must take into account the warnings made by specialists because in the area are reported danger data that anticipate other future risks.

Preservation and restauration are essential in order to recover from effects of the earthquakes, and the efficient measures are significant for the recovery and adaptability of the Norcia resilient community [20]. The studies that are being developed must be objective, otherwise there is the risk for material losses and human lives, as well as loss of specialist rights and penalties through large damages (as were the damages requested by the victims of the 2017 L'Aquila earthquake towards specialists who claimed before the earthquake that the area does not present an imminent danger) [21]-[23]. However, the inhabitants identify with the old city and they request the reconstruction works to be performed at a more alert rate.

Compliance of UN Sustainable Development Goals are part of the future of locality, and in the documents of the local administration, these objectives are described in detail and how they can be archived [25].

\section{ACKNOWLEDGEMENTS}

I would like to express my sincere gratitude to PhD Professor Architect Stefano D'Avino (UdA) and PhD Professor Architect Mihaela Criticos, PhD Professor Associate Architect Horia-Radu Moldovan and PhD Professor Associate Architect Kázmér Kovács (UAUIM) for the participation at the Workshop "Earthquake and historical center The urban walls of Norcia" Pescara - Norcia from 30 April to 5 May 2018. Thanks also for the other people or institutions that allowed the development of this workshop. At this event, I had a chance to collect a lot of data used on this paper.

\section{REFERENCES}

[1] Data bank: Biblioteca Riccardiana - Firenze. www.istitutodatini.it/biblio/images/en/ riccard/10928/dida/151.htm.

[2] Roseland, M., Toward Sustainable Communities: Solutions for Citizens and Their Governments, 4th ed., 2012.

[3] Life Cycle Initiative, www.lifecycleinitiative.org/paris-agreement-sustainabledevelopment-goals-life-cycle-thinking/. Accessed on: 19 Aug. 2018.

[4] TuttOggi, Norcia, tornano a suonare le campane della concattedrale Restaurate grazie al Rotary Club di Crema le campane di Santa Maria Argentea, posizionate al centro di comunità Madonna delle Grazie. https://tuttoggi.info/norcia-restaurate-le-campanedella-concattedrale/424479/. Accessed on: 25 Aug. 2019. (In Italian.)

[5] Norberg-Schulz, C., Genius Loci: Towards a Phenomenology of Architecture, Rizzoli, 1979.

[6] U.S. Geological Survey of 1500 GMT, Oct. 27/C.Iton 27/10/2016.

[7] Protezione Civile, Terremoto Centro Italia: Aggiornamento del numero di vittime, feriti e popolazione assistita, 26 August 2016. www.protezionecivile.gov.it/mediacomunicazione/comunicati-stampa/dettaglio/-/asset_publisher/default/content/ terremoto-centro-italia-aggiornamento-del-numero-di-vittime-feriti-e-popolazioneassistita. Accessed on: 25 Aug. 2019. (In Italian.)

[8] Pistolesi, I., La "buona ricostruzione" salva Norcia, danni contenuti, ANSA Politica, 24, 2016. www.ansa.it/sito/notizie/politica/2016/08/24/la-buona-ricostruzione-salvanorcia-danni-contenuti_811f0156-217e-422a-a941-383716a5cc68.html. Accessed on: 25 Aug. 2019. (In Italian.)

[9] Gallia, P., Galadinib. F. \& Calzonic, F., Surface faulting in Norcia (central Italy): A paleoseismological perspective. www.iesn.org/dida/norcia.pdf. Accessed on: 25 Aug. 2019. 
[10] Comune di Norcia, www.comune.norcia.pg.it/2018/05/31/esclusione-zona-rossa/.

[11] Sextos, A., Local site effects and incremental damage of buildings during the 2016 Central Italy: Earthquake sequence. Earthquake Spectra, 34(4), 2018. www.researchgate.net/figure/Damage-distribution-in-the-historical-center-of-Norciaa-after-the-24-August-event-and_fig11_323687016.

[12] Lopes, M. et al., How to survive earthquakes: The example of Norcia. Proceedings of the International Conference on Earthquake Engineering and Structural Dynamics (ICESD), pp. 403-412, 2017.

[13] D'Avino, S., After the earthquake the conservation before the conservation. Transsylvania Nostra, Comune di Norcia - Piano Regolatore generale - Parte operativa Marzo, pp. 34-40, 2019.

[14] Recuperati i documenti dagli archivi di Norcia, 16 March 2017. www.lavocedelterritorio.it/index.php/recuperati-documenti-dagli-archivi-norcia/. Accessed on: 25 Aug. 2019. (In Italian.)

[15] Norcia: Danneggiati da un incendio due container operativi del Comune Norcia, 4 March 2017. www.quotidianodellumbria.it/quotidiano/norcia/norcia/norciadanneggiati-da-un-incendio-due-container-operativi-del-comune. Accessed on: 25 Aug. 2019. (In Italian.)

[16] SAE, Consegnate le ultime 24 casette nel territorio di Norcia. Alemanno: "Sae Castelluccio uniche nel cratere. Ora sotto con la ricostruzione", 9 July 2019. www.comune.norcia.pg.it/tag/consegna-sae/. Accessed on: 25 Aug. 2019.

[17] Comune di Norcia, Piano Regolatore generale - Parte operativa Marzo, 2019. (In Italian.)

[18] Google Maps, 2019.

www.google.com/maps/place/06046+Norcia,+Provincia+Perugia,+Italia/@42.78816 $37,13.0933289,2969 \mathrm{~m} /$ data $=! 3 \mathrm{~m} 1 ! 1 \mathrm{e} 3 ! 4 \mathrm{~m} 5 ! 3 \mathrm{~m} 4$ ! 1s0x132e6be8fc647d55:0xc6d848f ace $77 \mathrm{faec} ! 8 \mathrm{~m} 2 ! 3 \mathrm{~d} 42.7916746 ! 4 \mathrm{~d} 13.0947335$.

[19] Commissione Europea - Comunicato stampa "Solidarietà all'Italia: 1,2 miliardi di fondi UE per contribuire alla ricostruzione dopo i terremoti”, Bruxelles, 21 June 2017. https://europa.eu/rapid/press-release_IP-17-1665_it.htm. Accessed on: 25 Aug. 2019. (In Italian.)

[20] Sendai framework for disaster risk reduction 2015-2030. Presented at Third UN World Conference in Sendai, Japan, 2015.

[21] Benessiaa, A. \& De Marchi, B., When the Earth Shakes and Science with it. The Management and Communication of Uncertainty in the L'Aquila Earthquake, Elsevier, 2017.

[22] Sentenza, N., Tribunal di L'Aquila. Sentenza nella causa penale, udienza del 22/10/2012, 380/2012. https://processoaquila.files.wordpress.com/2013/01/sentenzagrandi-rischi-completa-1.pdf. Accessed on: 25 Aug. 2019. (In Italian.)

[23] Corte Suprema di Cassazione, Cassazione Penale, sezione IV, 25 March, 12748. www.giurisprudenzapenale.com/wp-content/uploads/2016/04/terremotosentenza.pdf. Accessed on: 25 Aug. 2019. (In Italian.)

[24] Corte di Appello dell'Aquila, Sentenza 3317 pronunciata in data 10/11/2014 depositata in data 06/02/2015, 2014. www.scribd.com/doc/255215279/Grandi-Rischi. Accessed on: 25 Aug. 2019. (In Italian.)

[25] Panfili, M. \& Ghireli, P., Rapporto Ambientale, Cooprogetti, Provincia di Perugia, Comune di Norcia, PRG2019. (In Italian.) 